\title{
Cyberdemocracy as a Future Product of Political Systems Engineering
}

\author{
Andrzej Kaczmarczyk \\ Modeling and Simulation Department, Institute of Mathematical Machines, Warsaw, 02-078, Poland
}

\begin{abstract}
This paper discusses probable future political organization of democracy being a product of political systems engineering. Development of the Information Society and change of the parts of representative and direct democracy in the democratic paradigm are considered as socio-political premises for arising of a new form of "cyberdemocracy." Nature of the cyberspace, arise and development of e-civilization in it, e-democracy and e-voting, virtual communities and their other supportive cyber-means are discussed next as civilizational and technical premises. Finally, a vision of the cyberdemocracy system as a specific structure of cyber-communities immerse in the cyberspace is presented.
\end{abstract}

Keywords Cyberdemocracy, Cyber Communities, E-Civilization

\section{Introduction}

Present form of democracy, invented in the days of the horse and cart and perfected during the steam age, becomes to be incompatible with fast-altering world, more and more global, less and less territorially-anchored, networked and addicted to ubiquitous information in the electronic form, experiencing threats unimaginable in the past. In the reality of today's world informal subjects more and more play direct role in politics, and more and more things "are occurring outside the control of even the most powerful states"[1]. Democracy does not to have at all to be a guaranteed fortune of the humanity, but if it is to be kept, change of the form of democracy seems to be necessary. A new form, compatible with Information Society characteristics, so participatory, flexible, and networked one, must take advantage of cybernetic support and be born with assistance of systems engineering.

The thesis of this paper is that "cyberdemocracy", future political organization of democracy being a product of political systems engineering, will have a form of a hyperstructure of cyber-communities immersed in the cyberspace, with specific characteristics of legislative, executive and judicial powers, defense and fiscal functions, as well as nations' development.

The paper is organized into three sections. In the first two of them, premises - social, political, and next civilizational and technical - for cyberdemocracy arising are discussed. The last section presents a vision of cyberdemocracy model,

* Corresponding author:

kaczmarczyka@yahoo.com (Andrzej Kaczmarczyk)

Published online at http://journal.sapub.org/fs

Copyright (C) 2011 Scientific \& Academic Publishing. All Rights Reserved and challenges to political system engineering related to this model

\section{Social and Political Premises}

\subsection{Information Society}

Already invention of the telegraph gave Nathaniel Hawthorne an assumption to write that by means of electricity "the world of matter has become a great nerve" and "the round globe is a vast ... brain." First modern vision of global information society comes from Marshall McLuhan, which in 1960s developed a theory that the electronic communications media would transform the world into a "global village." In addition, many other authors foreseeing a shape of the new post-industrial society emphasized importance of information and electronic communication, and such names as "Electronic Era" or "Information Age" went to the vocabulary. At the turn of the century, these suppositions and forecasts have turned into political concept, and into program being put into effect - the concept and program of the "Information Society."

In 1994, both in the European Union and in the U.S.A., initiating events being milestones in the Information Society development took place. In Europe, a report titled "Europe and the Global Information Society. Recommendations to the European Council", prepared by a working group appointed by the European Council (and known as "Bangemann Report" from the name of the working group's chairman) was released. The Bangemann Report stated that "throughout the world, information and communications technologies (ICT) are generating a new industrial revolution already as significant and far-reaching as those of the past." "This revolution adds huge new capacities to human intel- 
ligence and ... changes the way we work together and the way we live together." The Report included an action plan for "implementing the Information Society," with concrete proposals of building blocks of information infrastructure: networks, basic services, and priority applications. In the U.S.A., a speech of Vice President Al Gore on the conference of International Telecommunications Union was the milestone event. "We now can at last create a planetary information network that transmits messages and images with the speed of light from the largest city to the smallest village on every continent," said Gore. Within the national boundaries of the U.S.A., provision of telephone and interactive digital video to almost every American was to be put into effect. Both in the U.S.A. and the EU development of the information society should be entrusted to private sector and to market forces with competition as a key element. In next years, governments of almost all developed countries proclaimed their policies, strategies, plans of action concerning information society development - among others outside of the EU: Australia and Canada in 1997, Japan in 2001, Russia in 2002. Similar documents came into being at transnational level, in G7 and G8, for Africa, for Asia-Pacific region, as well as for the whole world under auspices of the UN. The UN General Assembly adopted in 2001 a resolution endorsing the organization of the World Summit on the Information Society (WSIS), which was to offer an opportunity for governments and other involved actors to discuss and give shape to the information society. Political visions of the Information Society presented in those manifestos include first of all a statement that access to the cyberspace should be guaranteed everyone; in some announcements the right to the access is treated as one of fundamental citizens' or human - rights in the Information Society. Moreover, universal access at affordable cost, as well as elimination of "digital divide" between countries, regions, sectors and socioeconomic groups, are considered as essential problems. Furthermore, these political visions included depiction of some tasks, judged as the most significant, in economy, transport and communication, research and study, education, culture and entertainment, health, environment and agriculture, governance and public services, and others.

Advances and present state of the Information Society development, keenly monitored by numerous bodies and institutions, have been promising. The UN publication[2], including statistical data from 238 countries, presents some indicators of development. Therefore, there are 92 mobile phones, 62 computers, and 24 Internet subscribers per 100 inhabitants in developed countries; responding figures for developing countries are: 33,5 and 4. Moreover, one can observe permanent tendency to decrease differences. If the above indicators for developing countries are presented as percentage of indicators for developed countries, these percentage values increase in time. In 2000 percentage indicators related to mobile phones, computers and the Internet for developing countries were respectively: $12 \%$ (it means that in developing countries there was only $12 \%$ of this amount of mobile phones per 100 inhabitants what in developed coun- tries), $8 \%, 6.5 \%$. The same indicators in 2006 were: $36 \%$, $8 \%$ (no change here), and $17 \%$. Yet there is a group of 47 countries - so $19.5 \%$ of all countries - making up a group of the "least developed economies," in which information society is poorly advanced indeed.

In the $21^{\text {st }}$ century, information society will develop as postmodern society. This aspect will be discussed together with civilizational changes.

\subsection{Decline of Representative Systems}

Representative democracy in its present shape does not serve well the information society in its development. General changes that society and economy have undergone during more than two centuries deepened natural flaws ${ }^{1}$ of so far democratic system, and added new ones. The newest have appeared in the 20th century in the form of potent combination of professional political marketing, and modern industry of political lobbying. Political image making and marketing, electronic mass media oriented, use scientifically developed methods, tried in product selling, with focus rather on emotional not rational appeals. Already in radio political ads - as author of the report[4] has written - "there is very little of the rational approach in creating a political image," and in a political campaign: "the selling of a candidate is not unlike the selling of a luxury item." The same is going on with TV ads, and recently neuromarketing based on use of FMRI (Functional Magnetic Resonance Imaging) scanners, has joined in the toolbox. This new tool enables to observe how volunteers' (rather hired?) brains react to TV ads. Neuromarketing becomes the "fast-growing industry"[5], what calls the nightmare to turn the public into "roboshoppers" and "roboelectors". Professional firms of "political consultants" offer full arsenal of services to organize and carry on political campaigns. Costs of campaigns has skyrocketed, and the political struggle for power become not so much a confrontation of ideas and programs, but rather competition between professional means and methods in use, and financial resources necessary to buy it. Professional lobbying is a vital way to supply these resources. Activities carried out with the objective of influencing the political decision-making processes, always were present in politics. And in the second half of the 20th century, this process undergone commercialization, and lobbying has become - originally in the U.S.A. - a business cultivated by professional firms. The overriding aim of lobbying is to drive legislation important to a client through legislature or to kill legislation harmful to him, and lobbying firms offer a wide range of activities to get this aim. There are hundreds of lobbying firms in Washington, more then 120 of them reported in 2000 at least 1 million dollars in income; in 2005 there were 22 registered lobbyists and 2.7 million dollars of lobbying money per one lawmaker[6]. Corporations are main clients of lobbyists, and independent academic investigations[7] have revealed that fraudulent firms spend more on lobbying than firms not involved in fraud, and that fraudulent firms spend more on lobbying during their fraud periods than their non-fraud periods. Differences are stand- 
ing out, amounts dozens of percents, and results are significant for fraudulent firms because lobbying companies were able to evade detection longer than firms that did not lobby.

Confidence in representatives is disappearing. A worldwide poll, conducted by Gallup International for the World Economic Forum in Davos in 2006[8], found that six out of ten people think politicians are dishonest. In Africa, the ratio was eight out of ten.

\subsection{Reinforcement of Direct Democracy}

Democracy appeared on the historical scene as direct democracy (DD). DD is one of the most obvious ways of organizing a political community, is found in many primitive societies, and its origins go back to prehistoric times. DD was practiced both in native America[9] and in barbarian Europe[10]. Decisions were taken in public gatherings according to the principle of majority rules, however not voting but acclamation procedures were in use. In barbarian Europe shaking with spears represented approval, what Latin chroniclers named: deciding per gairethinx (gaire means "a spear" in Longobard dialect). Advanced forms of democratic - in fact direct democratic - rules were practiced in ancient Greece, where all citizens of a state were entitled to attend popular assembly, make proposals of laws or policy, debate them, and decide by ballot. Greeks justified lottery appointments in the interest of absolute equality of citizens (what Aristotle considered as one of the characteristic features of democracy), and barbarians justified it by citing that decisions were gods' will manifested by them in the lottery act. Until now, because of poor communication and information distribution abilities, DD could not serve as a basic form of rules in large-size states. Yet DD practices survived other regimes and were cultivated when representative democracy arose, assuming the form of referendum. Constitutional referenda were organized in American colonies when the U.S.A. was coming into being and in France during the French Revolution. DD, just in the forms of referenda and citizens legislative initiatives, is well anchored in the present democratic systems. Overall thousands of DD acts have been conducted at nationwide or statewide level in many countries since the end of the 18th century; thousands are being conducted each year at the local level.

DD functioning was a subject of fruitful sociological experiments developed in Germany under the name Plannungszellen (Planning Cells)[11] and in the U.S.A. as "Citizen Juries"[12]. Planning Cells are randomly selected groups of citizens being demographic approximation of the whole population in respect of gender, age, income, and level of education. Since the 1970s, Planning Cells technique has been implemented hundreds time at different levels from local to national in Germany, the U.S.A., and in other countries. All those experiments have undoubtedly proved that it is possible to get mature and valuable political recommendations for difficult and important matters in this way meaning directly from ordinary people.

Also in the 1970s, "Televote" experiments began to be conducted in the U.S.A. In those experiments televoters, that before the ballot had received by mail a packet of information about the issue under consideration, voted by phone from their homes. Then Electronic Town Meetings (ETM), similar to the televote, but organized with joining of radio and TV in the projects and with participation of thousands of people, were organized[13]. As well, these undertakings have proved the same as experiments with Planning Cells. Moreover they showed that electronic voting from the most natural citizen's environment i.e. his own home encourages people to participate in the public life - demographics of respondents almost exactly coincided of demographics of the whole population, while in normal voting participation of young people, women, less educated persons, cultural minorities was reduced.

Yet its adversaries still put some arguments against DD forward. General argument reads that ordinary people are not able to evaluate complex situations properly and to make responsible decisions. The rebuttal is offered just by supportive results of many thousands already conducted referenda, as well as by results of rigorously constructed and observed experiments with Planning Cells, televote, and ETM. Other argument brings up a threat of enormous variety of proposals to vote in DD conditions, but experience of parliaments proves that the number of proposals doesn't rise with the number of MPs - i.e. the number of entitled to submit a proposal ${ }^{2}$; moreover ICT delivers some remedies. Finally, both adversaries of DD and those doubtful about its feasibility spot that in fact, people are not interested in busying themselves with public matters - they have their lives to live and do not want to spend their time dealing with running the country. That is right, but the possibility to participate for all, not total participation is the essence of DD, and only $1 \%$ electorate participation in a referendum gives incomparably broader range of citizens' will expression then a representative body.

Direct democracy is a very natural way of democracy cultivation, comprehensible and acceptable even for members of primitive societies, and direct participation in the making of public policy overcomes political alienation and apathy. DD needs and accepts leaders-by-influence, having ability to create visions that would inspire people and to attract followers not subordinates, the leaders that have not to be appointed by election. At last, DD is free from costs of representative institutions, so can be an inexpensive solution. Therefore, if only limitations that in the past prevented the development of DD outside of an ancient city or tribe stop to be in force, then DD comes out as a candidate for the cornerstone of the political system.

\section{Civilizational and Technical Premises}

\subsection{Cyberspace and E-Civilization}

The cyberspace is the most complex artifact created by humanity so far. Internet, being network of networks, constitutes its core with what digitized telephones, radio, TV, as 
well as interception and positioning systems become integrated and interoperable. The Internet, thus the cyberspace as a whole, has neither its proprietor nor ruler, belongs to everybody and nobody, is a public, cooperative, and self-sustaining facility accessible to hundreds of millions of people worldwide. The cyberspace is an emanation of human society and is not fully controlled by humans, as the society itself. Cyberspace's properties, first of all its globalism and no-territoriality, cause that it does not fit the present democratic paradigm relying on states' sovereignty in their geographical borders. E.g. Working Group on Internet Governance, brought into being under the UN auspices, identified a number of important issues to discuss and negotiate on the WSIS forum of 175 countries, but results of negotiation on two WSIS parts in Geneva in 2003, and in Tunis in 2005, were unsatisfactory. It was stated only that the Internet governance poses a "complex universe" including many different types of issues, actors, institutions and rules, and that the governance has to be treated as a multi-stakeholder process in which there is no one governance size that fits all. And the conclusion was that different multi-stakeholder models, taking into consideration the private sector, civil society, and government, are needed in different issue areas. However, it is doubtful in my opinion if designing of consistent and efficient such models is attainable under present political structure of democracy, designed for territory-oriented basic formations of the society.

The cyberspace constitutes the medium of rise and development of e-civilization, just characterized by skills to manufacture e-tools and use them in the cyberspace, similarly as skills to manufacture stone tools and use them in the physical space characterized the Neolithic civilization. In the e-civilization, information in electronic form can be accessible at the same time in different places, and can be multiplied without limits. Moreover, before the e-civilization, information recorded on clay tablets or on paper was not alive; one has to read it and set in motion some process of its utilization. Information in electronic form potentially is "organic," as information included in genes, meaning that it can immediately activate and control processes - in both a material and informational nature - in which it is utilized. Everyone can daily make use of this common accessibility of information, as well as of automated information procedures in every circumstance of his/her life. Yet human life is becoming more dependent from influences of an incorporeal information or virtual - nature. In the present economy buying and selling money, in fact in the abstract form of electronic records, predominate other economic activities ${ }^{3}$, and the fast-changing flow of abstract money can decide the lot of peoples and nations. Other nonmaterial goods play a more and more important role, so "knowledge based economy" is characteristic for e-civilization. Above features are accompanied by e-civilization's extra-territoriality, being a consequence of properties of the cyberspace that enables non-territorially-limited activities, what gives birth to virtual communities of different type. Present political paradigms, binding citizens rights and duties with a specific territory, while people's vital interest are elsewhere, would be an inappropriate solution leading to wrong decisions and to a real restriction of people's rights.

E-civilization will realize itself in the postmodern world, where new social forms are coming into being. According to Michael Foucault, dispersed "biopower" - as Foucault put it into words: "exercised from innumerable points, in the interplay of non egalitarian and mobile relations" - regulates social life from its interior and control over society members is exercised through "flexible and fluctuating networks"[15]. Un-reality of influences that drive socio-economical processes in postmodern world of e-civilization finds its reflection in "simulacra" theory of Jean Baudrillard. According this theory, in contemporary society the signs of culture and communication media - just these simulacra - create the reality we perceive. "Facts no longer have any trajectory of their own," states Baudrillard, "they arise at the intersection of the models; a single fact may even be engendered by all the models at once"[16]. The paradigm of parliamentary democracy was not designed for postmodern world conditions. Democratic control over society members through flexible and fluctuating networks needs highly participative paradigm. A relatively narrow circle of politicians- representatives could create or interpret simulacra in a false manner, but misleading interpretations are unlikely to be made by the public using its collected wisdom ${ }^{4}$.

\subsection{E-democracy and Electronic Voting}

One can perceive three stages or consecutive models in the e-democracy development[17]. At the lowest first level, e-democracy fulfills no more then informative function not challenging the present structure of representative democracy. At the second level public debate becomes a political tool, and strongly influences, even binds, representatives and officials. At the third level, citizens directly participate in political decision-making. E-democracy trials in the form of televote and ETM started at the third level, but in practice e-democracy has been stuck somewhere between first and second level. The center of gravity of e-democracy in its real embodiment is situated in the matter of explanation of action of those governing, and ensuring better, interactive connection between representatives and their electorate - with the aim "to make representative democracy more representative."

Usually the tandem "e-government and e-democracy" is a theme of considerations, and in fact e-government area includes electronic information made available by administration to citizens, necessary for their participation in democratic activities at all levels of advancement. Yet, from web sites of governments, municipalities, and official political entities, only some participative options can be rated among exact e-democracy subjects. Web sites typically offers citizens a possibility of contact by e-mail, and taking part in different form of e-debate (discussion group, blog, chat); government institutions' newsletters with possibilities to send questions and comments, as well as live hot lines are practiced also. E-petitions and e-consultations are more 
advanced forms, in which some statutory regulations are introduced. Since 2000 in UK, and since 2002 in the whole $\mathrm{EU}$, codes for e-consultation mechanisms - but without any obligation for governing organs to put into effect obtained recommendations - have been introduced. Municipal web sites, offering the same contact and debate possibilities, and even greater in consultation, furthermore enable self-organization of inhabitants sharing the same interests or needs. Web sites of parliaments and of political parties repeat the schema: to deliver information and to give the opportunity to express opinion. Thus, above form of electronic democracy practicing in fact are more effective implementations of traditional democratic (and pre-democratic) routines: citizens' letters and petitions, debates and consultations, and first of all information with use of political ads.

Besides official democracy domains, there exists the domain "citizens online" that really opens new prospects for democracy. The domain gives unprecedented possibilities of extra-territorial self-organization on the global scale, based on the most universal many-to-many communication scheme (both communication between government and citizens, and between subscribers and public media are of the one-to-many and many-to-one schemes). Web sites of individual persons, independent organizations, and institutions exist in the cyberspace, and newer and newer ways of participation in group activities related to these Web sides' topics and content appear. "Citizens online" domain includes independent, free activities of people in the cyberspace, multidirectional and with many points of concentration and coordination. This domain represents freedom combined with self-organization ability, and will become an incubator of new forms of an ICT-driven democracy.

Electronic voting is the key tool of electronic democracy, necessary to achieve the third level of its development. Moreover, both technology and use of electronic voting are quite well advanced now. More than one billion of people in the world cast their public ballots electronically, among them more then a hundred thousand via the Internet. India, Brazil, and the U.S.A. are the biggest electronic voting systems users. In India and Brazil governments, have introduced electronic voting in a centralized way, with use of identical equipment in the whole country, designed for the government. In Brazil, electronic ballot boxes were used for the first time in 1996 in big towns only, and then their application was successively widened[18]. In 2002, first electronic national election, with use of 400 thousand voting machines, was conducted in Brazil having 115 million electorate then. Brazilian electronic urnas were simple special-purpose computers priced about $\$ 420[19]$. In India, electronic voting was firstly tested in local elections in late 1990s, and used on a mass scale during the election of the national parliament in 2004. India had then the electorate of more than 668 million, and over one million voting machines were used in the election. Indian voting machines are even of simplest design and use than Brazilian ones, "easy to operate, even by the illiterate," priced at \$230[20]. Both in Brazil and India voting systems turned out to be efficient, and complaints on ballots results did not constitute any severe problem. In India, the "electronization" of the election was performed under the rule of Bharatiya Janata Party, and the opposition Congress Party unexpectedly won the 2004 election, what can be an argument for trustworthiness of the chosen electronic solution. In the U.S.A. situation is different. The country of one hundred million electorate has the biggest experience with electronic voting which has been conceived here, but also the biggest mess and controversies about the subject. Voting machines of different type made by different firms and in different years are in use. Besides newest machines that cost as much as $\$ 3000$, devices even a few dozen years old are still in use. Choice of the equipment to buy, and decision to apply it, belongs to states or even local authorities. Therefore, critical opinions are frequently propagated, and during consecutive elections, legendary incidents occur. This situation caused that in the U.S.A. means to remedy faults have been made - in the form of performance standards and certification system. The Federal Election Commission (FEC) has developed the standards - with participation of "state and local election officials, independent technical experts, election system vendors, Congressional staff, and other interested parties" since early 1980s. The current standard, authored by newly created the Election Assistance Commission (EAC), and named "Voluntary Voting System Guidelines" (VVSG), was released in 2005. On the base of VVSG, and with support of the National Institute for Standards and Technology (NIST), certification activity is developed with involvement of laboratories authorized by EAC. The standard and certificates are voluntary, not obligatory, and in practice voting machines not tested and not having certificates were sold and installed in the U.S.A. Troubles with electronic voting largely depend on factors connected not so much with technological development, but with current political paradigm. Yet American approach to the electronic voting, with its multidimensional diversity, is compatible with the future cyberdemocratic system and will find continuation in it.

Internet has been used for informal voting for a long time, and since the beginning of 2000s for binding voting, both private and public. A number of such pilot elections and referenda have been conducted via the Internet in different countries. In Swiss cantons Neufchatel, Zurich and Geneva pilot systems were implemented and a dozen of internet votings were conducted between 2001 and 2008. In France pilot system, enabling cast votes by both PC and mobile phones was used for election of Issy-les-Moulineaux inhabitants' representatives for the District Council in 2002 and 2005. A number of voters casting their ballots over the Internet in these Swiss and French undertakings came between a few hundred and a few thousand. More mass participated was election of the Arizona Democratic Party candidate for the U.S. President, so called primary election in 2003 , in which almost 40 thousand voters used the Internet. In addition, a true breakthrough has been done by Estonia that became the first country in the world to hold an election allowing voters nationwide to cast ballots via the Internet. 
After local trial referendum in Tallin, the Estonian system of internet voting was used in local elections in 2005[21], and then in national parliamentary election in 2007[22], with participation of almost 10 thousand of internet voters in the first event, and more than 30 thousand in the second one. Internet voting is in its infancy now, but grows up quickly.

\subsection{Virtual Communities}

Non-place communities based on communication with the use of computers began to arise as soon as the possibility of such communication appeared[23]. Origins and aims of these Virtual Communities (VCs) have been diverse, just as diverse are social groups based on conventional methods of communication that come together around mutual interests and actions. The cyberspace is populated by a myriad of discussion lists, blogs, photo, and video-sharing sites, both affiliated with institutions and individual persons, which all can be perceived as VCs. Some kinds of VCs can be discerned from the point of view of software they use to realize their aims.

Communities of computer gamers use MUDs (Multiple User Domains/Dungeons) software that allows players to function in virtual reality interacting with each other. "Second Life" that appeared in 2003 is something more than a game - it is a virtual world built by community members. They can create their artificial alter egos "avatars" and lead their "second life" moving, chatting, having sex, buying, selling and so on. Moreover, the virtual reality interacts significantly with economic and social reality. Real companies (Reebok and Toyota among them) have their outposts in this virtual world, one can find there diplomatic posts of real countries as well, and virtual money used in Second Life's transactions has its exchange rate to U.S. dollars.

E-learning communities gather their members for educational purposes. The beginning of distance learning by the Internet date back to the 1990s and now e-learning is a whole world-wide industry, worth dozens of billion of dollars. Self-paced courses that can be accessed twenty-four hours a day are possible whenever they are needed. Software of e-learning enables one to turn any existing content - information from electronic documents, presentations, screen captures, recorded voice information - into online teaching. The e-learning has its own standards - including standard language eLML based on metalanguage XML - ensuring interoperability.

Communities, having as their aim collaborative authoring of particular content, use "wiki" software enabling collaborative editing of content of the Web pages. The most famous is the community of Wikipedia, the Free Internet Encyclopedia (Wikipedia was bestowed the "Golden Nica" award by the Ars Electronica Center in Linz, Austria, exactly in the "Digital Communities" category). Wikipedia has its competitors and imitators, and on the Internet, one can find a good deal of Wikipedias oriented on particular subjects.

There is also a numerous group of VCs of different kinds of associations having legal personality, which go in the cyberspace for their activities. These VCs do not use any particularly focused software because they realize aims characteristic for many societies. Typically, the software enables:

navigate the site and search content;

subscribe to discussion (e-mail-based) and participate in it with use of the threaded discussion view, start discussion, moderate discussion;

create documents collaboratively, also sharing information that members can read at an external web site and linking the content directly to an external web site without leaving the community;

exchange, download and upload files, including images and voice;

post "calendar entries" i.e., time-sensitive information on events, schedules and so on, and get calendar reminders;

create databases and add records to them;

start polls and conduct them;

have real-time communication among members, chat, and

find out who is online;

create and review member lists and profiles.

The software tools are usually accessible to communities as a service provided by firms busy with "social software."

VCs with political competences will become atomic elements of the cyberdemocracy structure.

\subsection{Supportive Cyber-Means}

Of course, the software in VCs' use is helpful for online democracy development. What's more, there is a reach toolbox of software recommended for e-government and e-democracy[24]. And aside from this, there is a number of cyber-means developed for other areas but supportive for the future cyberdemocracy.

One of them is group work technology giving computer assistance for teamwork on the web[25], developed for business needs - American organizations held 15 million meetings per day, and corporations spent more than 37 billion dollars annually on meetings, of which $40 \%$ were rated as unproductive. Initially, this technology enabled only the substitution of face-to-face meetings, which demanded costly business trips, by web conferencing. The second generation of group work systems, which appeared on the market in the 2000s, was designed for collaborative decision-making with making the most of group intelligence in order to increase meetings' productivity. Individual group work technology firms have hundreds of clients. Collaborative decision-making sessions are organized for needs of corporations, banks, government and municipal institutions, military, intelligence, and others. Many clients installed and permanently use their own systems.

Other helpful instrument is Online Dispute Resolution (ODR), enabling resolution of contentious issues in an alternative way - outside of the government judicial process with the use of online methods of negotiation and mediation. Today's ODR solutions, making it possible to run multi-party negotiations/mediations in a secure manner, and 
to work on a number of cases simultaneously, are offered to the public as a service provided by firms using their own ODR systems, or as a sale of software to install; according to[26] there were about 25 providers of ODR in 2006.

Also supporting muscle of data mining techniques, as well as of forecasting methods of the "electronic prediction markets" type, absorbing the collected wisdom of thousands of participants[27], can't be overestimated.

\section{Expected Cyberdemocracy and Challenges to Political Systems Engineering}

\subsection{Cyber-Communities and Their Hyperstructure}

In the e-civilization, development of the ICT will make possible to do almost all what is thinkable, with any information, on a scale of the whole humanity. It will really be such, as though the whole humanity with its total information resources was situated on a single forum in the cyberspace, where an arrangement of any pattern of information exchange between the participants, as well as any pattern of information processing, was possible. And this cyberspace's extraterritorial forum is populated by a myriad of VCs.

Cyberdemocracy is to be a political system developed exactly for such conditions. Therefore, it suggests itself that VCs having political competences - let us call them cyber-communities (CCs) - will be basic forms of organization of the society under the cyberdemocracy paradigm.

CCs will evolve from territorial communities because of their going in the cyberspace for more and more of their activities. In time, non-place VCs, gathering people that have common interests neither limited by - nor bound to - a specific territory, will join political space of the cyberdemocracy as equal CCs. The cyberspace - its organization, rules, and solutions - seems to be the forefront area of competence and activities of such no-territorial CCs. CCs can arise at different levels of participation, and because there will be the possibility to belong to different communities simultaneously, a CC's membership can be perceived as hypermembership, with some analogy to the hypertext in the Web, a phrase of which can belong - be linked - to different websites simultaneously. CCs will make up together a specific hyperstructure in the cyberspace. Joining a $\mathrm{CC}$ will be something like contemporaneous registration as a voter; it will be a voluntary act, feasible under condition that someone has rights to participate, and probably connected with commitment on paying taxes - membership fees. CCs will have different raisons d'être but something essential in common: with its members being permanently in touch and an e-voting system at its disposal, a CC will be able to make decisions directly by ballot, without appointing representatives, so will be able to play a role of its own legislature. Thus, CCs will realize a variety of electronic direct democracy variants using information resources and online services offered in the cyberspace by private firms, public institutions, and open sources.

A totality of all people-members involved in the cyberdemocracy paradigm will be fundamental formation of the hyperstructure; it can be perceived as a basic $\mathrm{CC}$ of the paradigm. This basic CC can change in the course of cyberdemocracy spreading, but finally, because of globalization tendency, it will probably encompass just the whole humanity. If, in the process of cyberdemocracy evolution some basic CCs that have developed separately so far will join, they form a new basic $\mathrm{CC}$ together. The basic $\mathrm{CC}$ can be described as the superset of all its CCs, so all CCs belonging to the hyperstructure, being sets of their people-members, will be its subsets. Because individual persons can be members of different CCs simultaneously, all possible relationships between these subsets can occur: CCs can be disjoint sets, one CC can be a subset - or superset - of another CC, and subsets representing CCs can intersect. It is obvious that such hyperstructure couldn't exist as a functioning formation without cybernetic assistance.

\subsection{Cyberdemocracy's Functions and Properties}

Ways to exercise legislative, executive and judicial powers in the new paradigm will be distinct than present, new situations will arise and new solutions - however in some cases taking inspiration from very old ones - will appear in the fiscal and defense domains, as well as in national life continuation.

In the legislative area, although any revolutionary new law system won't be created from roots, further development will be caused to a lesser degree by individual or elite-group "great legislators", but rather will ensue as a result of functioning of a "common law" system in which the law is created and refined on the basis of concrete precedents that binds future decisions.

The division between legislative and executive competencies will be rather fuzzy, similarly as it was in ancient popular assemblies. However, in the information society which fulfills a lot more complicated functions than ancient society, and has the use of a much more complicated infrastructure, to keep professionally efficient executive organs is a necessity. CCs will hire these organs, persons with proper expertise or professional firms, rather than appoint them from among members at large. In general, relations between a $\mathrm{CC}$ and its executive will resemble relations between shareholders and executive in the corporate world, rather than relations between subjects and government in a state. Means to control executives applied in corporation statutes and manager contracts, enriched by ICT-based new ones (e.g., collective counter-signature), will be in use.

In the judicial branch, out-of-court methods of ODR will find their broad application in both civil and criminal law[28]. If it will be necessary to bring a case to court, it'll be adjudicated in a virtual courtroom being "not a physical location but rather the interchange of high-quality audio, video, text, and graphical information among trial participants without concern, except for jurisdictional requirements, for the physical location of those participants"[29]. Different 
judicial systems will function under the cyberdemocracy as a kind of public service retaining independence, among which CCs - and probably individual members within the confines of their CC - can make a choice. The solution with different judicial systems functioning in a single state is well tried during the human civilization development, had its applications in post-Roman barbarian kingdoms, in medieval Europe as separate town law being a burger's privilege, and is practiced now in federal states. Punishments, such as financial penalties or restriction of civic and other rights, can be executed and controlled through the cyberspace. Restriction of liberty also can be controlled by means of "electronic fetters" attached to a person, allowing his/her whereabouts to be monitored. In the cases of criminals posing a serious threat to society, who must be isolated, some form of forced detention will be applied, probably at the crossroad with institutions of involuntary psychiatry. Both, monitoring by fetters and isolation, will be entrusted to hired private firms, as it becomes to be practiced now.

Defense functions, fulfilled by the military and attributed historically to territorially grounded states, will evolve into a professional service, dedicated to law enforcement on a global scale rather than to the defense of a territory. Fiscal issues will be handled in a natural way in the cyberspace, where economic life of the Information Society is assembled.

Nations will have their second life after nation-states as nation-CCs in the cyberdemocracy. In many dissertations[30][31][32] nation is depicted as "a soul, a spiritual principle" or with other words as an "imagined community" in the minds of members of which "lives the image of their communion". Because "two men are of the same nation if and only if they share the same culture, where culture in turn means a system of ideas and signs and associations and ways of behaving and communicating," there is the possibility of existence and development of nations outside of any particular territory, in the cyberspace. Even hypermembership in national CCs can be a solution for the future, and can prevent the washing away of nationality in the coming epoch of "universal nomadism".

The 21st century will be an urban century. Already in 2007 a number of cities inhabitants surpassed a number of country inhabitants on the Earth, and the share of city inhabitants is expected to rise to $60 \%$ by 2030 [33]. On all continents, urban areas and megacities are increasing their hold in economic, cultural, social, and political areas. Due to migration processes - cities are points of concentration of the universal nomadism - the population of cities is increasingly differentiated, cities' e-infrastructure is well developed, their experience with e-government and e-democracy outstanding. These circumstances make a city a potential incubator of CCs of different character, and its hyperstructure.

Openness and narrowed privacy will be significant attributes of the cyberdemocracy functionality. Privacy becomes more and more washed away as the development of the Information Society advances. Electronic information about individuals is collected and aggregated by many in- stitutions with different ends in view, and abilities to share this information between them are strengthening. Different systems of electronic surveillance are developing also. There is no way to stop this tendency and to limit the passing of privacy. However, a Big Brother ghost - meaning the possibility that information gathered on citizens' private matters will be accessible only for some privileged persons and institutions - should be tethered by the openness. The cyberdemocracy is fated to openness also for the sake of legislative power belonging to every member of the community, as well as the ability to be appointed by lottery to different functions; it makes necessary everyone's transparency if she/he wants to enjoy a full citizen's rights. The less-privacy-more-openness option not only is a necessity but also will bring an important benefit for global society in the matter of the increase of its homeostasis. A phenomenon of sound homeostasis of smaller communities, in which information of members' actions and condition reaches everyone, can also become a benefit of geographically dispersed greater clusters of people joined by information bonds.

One of dilemmas of present democratic order in the epoch of growing migration is contradiction between the respect for cultural heritage and autonomy and demand for integration. Integration is to be conducted based on some "core values" which can be demanded from every citizen, while only determined "areas of difference" should be maintained and respected. The cyberdemocracy functioning in the infinite cyberspace, with the vast possibility of creation of CCs in which people can build their life according to their beliefs, offers just conditions in which larger areas of difference are acceptable, and fewer common core values are established. The problem of coping with differences on the fora of CCs of a higher level of participation, particularly with differences caused by various cultural backgrounds, can be solved maybe with use of ICT means accessible in the cyberspace. Use of avatars in political debate can eliminate strangeness, facilitate mutual understanding, and cause focusing on the debate content. Ecologists argue that biodiversity, a rich bank of genes, is essential for the survival and development of the earth's ecosystem. Similarly, a rich bank of outlooks and beliefs cultivated in the vast political space of the cyberdemocracy can be essential for the survival and development of humanity. In some unpredictable circumstances, in the turn of human history, any particular reliance or attitude can be a center of crystallization of beneficial ideas and behaviors.

\subsection{Challenges to Political Systems Engineering}

Political system of cyberdemocracy will rather arise expressing it with use of E.C. Raymond's formulation from his famous essay - on a bustling open bazaar than as a carefully planned cathedral. The system will be built by its collective architects having at their use implicit models, not blueprints. Therefore, it is necessary to create resources enabling to achieve the aim in such a way. Resources should include means of the type of standards ensuring possibilities 
of integration and interoperability, as well as of the type of system tools.

Solving the problem how votes of members of CCs are to be aggregated to yield a result in the hyperstructure is a key challenge. Voting theory, developing since the $18^{\text {th }}$ century, has been focused chiefly on electoral methods - how to elect representatives, both in single member and multi-member representation - and a voting system for the hyperstructure of CCs will be a new challenge. One can expect that the principle of multiple counting of votes will find its application here. With respect to the rule that an individual person, regardless of her/his membership in different CCs, is entitled to only one vote in a given matter of a ballot, the final result is to be calculated as a multiple majority of voters and communities involved. In Switzerland, in the case of vote a citizens' initiative as well as in the case of an obligatory referendum, the principle of double majority is in force - i.e. all the votes cast are counted twice, once for the overall number, and then for each separate canton. The proposal passes if a majority of those who voted, and a majority of the cantons is in favor. Double counting is sufficient for two-level structure of cantons and the federation, but complexity of the hyperstructure will need more sophisticated aggregation in some dedicated multiple counting system.

An already existing challenge is the problem of management of the Internet as a "complex universe." As it was said previously, it is doubtful if designing of efficient multi-stakeholder models for use of the Internet management is attainable under present territorially oriented democratic paradigm. Yet searching for the problem solution apart from the exact present political conditions, assuming stakeholders of the CCs-type, could be very informative project opening the field of investigation on decisions taking in the hyperstructure.

Introducing redundancy successfully applied in Nature as well as in technology, for raising systemic security is another challenge. E-voting security is an essential problem, which can be accomplished with use of redundancy. A set of parallel board computers is applied in avionics systems to ensure flight security. If there is a difference between computing results of usually four computers (quadruple redundancy), a proper action is undertaken. Similarly, several systems, of different ownership and/or geographical location, could be employed to conduct an Internet vote. Polls have a feature that can be repeated if there is a doubt about results, which occurs not infrequently during conventional elections and referenda. With the use of Internet voting systems, round the clock ready for service, repetition of voting - because of intolerable differences between parallel systems outputs will be much easier.

The problem of effective control of hired executives by CCs members also needs searching for new solutions. Collective counter-signature system can be one of them. In such a system the backing electronic signatures of some percent of a CC's members would make a decision workable, and without such backing e.g., a money transfer would be automatically blocked. The system could work in such a way that for the appointment of an executive his backing by a certain percent of CC's members, in the form of giving him electronic signatures in advance, is necessary. Then, each individual backing could be withdrawn for an unwanted decision, which needs counter-signature.

\section{Conclusions}

One can take a risk to make a thesis that building of general political intellect of the humanity is the general challenge to democratic system engineering in the e-civilization epoch. In more holistic approach, without focus on political aspect, "general intellect" is a concept of economic provenience, with its origin in Marx's works - productive labor has a tendency to become increasingly immaterial, so evolves towards general intellect. In present-day studies, general intellect is defined as "a collective, social intelligence created by accumulated knowledge, techniques, and know-how"[34]. This socio-economic concept meets its cybernetic counterpart: "global brain" or "super brain." The World-Wide Web of the Internet is in different aspects similar to a human brain, and is likely to become more so as it develops. There is an analogy between hypertext and associative memory, as well as some similarities in the process of learning. Moreover, the Web would learn from its users, while the users would learn from the Web, so the brains of the users themselves would become nodes in the Web. "In the end the different brains of users may become so strongly integrated with the Web that the Web would literally become a "brain of brains": a super-brain." Cyberdemocracy with its hyperstructure in the cyberspace can be a specific organizational base for building a collective political intelligence able to deal with matters as they come, and making decisions not dictated by personal bias, greed or ambition - so can be an aspect-embodiment, focused on politics, of the general intellect.

The author's book "Cyberdemocracy. Change of democratic paradigm in the 21 st century" has been published by Key Publishing House Inc., Toronto in 2010.

\section{ACKNOWLEDGEMENTS}

The author would like to thank Alexa Fenwick for language correction of the article.

\section{REFERENCES}

[1] J. S. Nye Jr., "The Future of Power”, Public Affairs, 2011

[2] "The Global Information Society: a Statistical View", United Nations Publication LC/W.190. April 2008

[3] J. J. Rousseau, "Considerations on the government of Poland and on its proposed reformation" 1772

[4] M. B. Leidman, "Imaging and Political Packaging", paper 
presented at the Nation's Capital Chapter of the Hunter College Alumni Association, Washington, DC, May 1990. [Online]. Avaiable:

http://www.eric.ed.gov/ERICDocs/data/ericdocs2sq1/content storage_01/0000019b/80/13/ba/de.pdf. Access date March 2007

[5] T. K. Grose, "What Makes Us Buy?", Time, September 18, 2006

[6] J. H. Birnbaum, "The Road to Riches Is Called K Street", Washington Post, June 22, 2005

[7] F. Yu, X. Yu, "Corporate Lobbying and Fraud Detection. Preliminary Version". [Online]. Available: http:/www.soxfirst.com/50226711/lobbying.pdf. Access date January 2007

[8] P. Gumbel, "No More Heroes", Time. [Online]. Available: http://www.time.com/time/magazine/article/0,9171,5010601 30-1151845,00.html\#ixzz0YoU73q5S. Access date January 2006

[9] D. A. Grinde Jr., B.E. Johansen, „Exemplar of Liberty: Native America and the Evolution of Democracy", 1990. [Online]. Available:

http://www.ratical.org/many worlds/6Nations/EoL/.index.ht $\mathrm{ml}$. Access date May 2011

[10] K. Modzelewski, „Barbarzyńska Europa”, Warszawa, Iskry, 2004

[11] P. C. Dienel, Der Bürger als Chance“, Der Bürger im Staat, $3 / 1971$

[12] Citizens Jury Handbook", the Jefferson Center, 2004. [Online]. Available:

http://www.jefferson-center.org/index.asp?Type=B_BASIC $\& \mathrm{SEC}=\{50312803-2164-47 \mathrm{E} 3-\mathrm{BC} 01-\mathrm{BC} 67 \mathrm{AAFEA} 22 \mathrm{E}\} \&$ $\mathrm{DE}=\&$ Design $=$ PrintView. Access date May 2011

[13] T. Becker, C. D. Slaton, "The Future of Teledemocracy", Westport Conn., London, Praeger Publishers, 2001

[14] D. Harvey, “A Brief History of Neoliberalism”, USA, Oxford University Press, 2005

[15] M. Foucault, "The History of Sexuality: An Introduction/The Will to Knowledge", London, Penguin, 1990

[16] J. Baudrillard, "Simulacra and Simulations in Poster, M" in "Jean Baudrillard's Selected Writings", Stanford University Press, 1988

[17] J. Åström, "Should Democracy Online be Quick, Strong, or Thin", Communications of the ACM, 44(1), 2001

[18] E. G. Northfleet, "Communiqué on 3ème Forum Mondial de la Démocratie Electronique, Issy-les Moulineaux, 11-12 avril 2002"

[19] L. M. Mira, "For Brazil Voters, Machines Rule", Wired News. [Online]. Available: www.wired.com. Access date January 24,2004

[20] S. Vir, Electronic Voting Eases India Elections", IEEE Spectrum, 8/2004

[21] F. Breuer, A. H. Trechsel, "Report for the Council of Europe. E-Voting in the 2005 local elections in Estonia", March 6,
2006

[22] A.H. Trechsel, et al., "Report for the Council of Europe. Internet voting in the March 2007 Parliamentary Elections in Estonia”, July 31, 2007.

[23] H. Rheingold, "The Virtual Community", Addison Wesley, 1993

[24] M. Leighninger, "Using Online Tools to Engage - and be Engaged by - The Public", Report from IBM Center for the Business of Government. [Online]. Available: http://www.businessofgovernment.org/sites/default/files/Usi ng\%20Online\%20Tools\%20to\%20Engage $\% 20$ The\%20Publi c.pdf. Access date May 2011

[25] R. Roszkiewicz, "GDSS: The Future of Online Meetings and True Digital Collaboration?", The Seybold Report, 1/1, January 2007

[26] A. Elisavetsky, (2006). "Nuevas tecnologías de información y comunicación aplicadas a la resolución de conflictos". [Online]. Available:

http://www.mediate.com/articles/nuevastecnologias.cfm. Access date May 2011.

[27] J. E. Berg, et al., "Results from a Dozen Years of Election Futures Markets Research" in "Handbook of Experimental Economic Results”, North Holland, Amsterdam, 2003

[28] G. Mackenzie, et al., "Decision Support for Criminal Sentencing and Plea Bargaining", Law and Technology, 2007, Sept. 24-26, Berkeley, USA

[29] F. I. Lederer, "The Road To the Virtual Courtroom? A Consideration of Today's - and Tomorrow's - High Technology Courtrooms", presented at the 16th International Conference on Technology and Its Effects on Criminal Responsibility, Security, and Criminal Justice, 2002. [Online]. Available: http://www.isrcl.org/Papers/Lederer.pdf. Access date May 2011

[30] E. Gellner, „Nations and Nationalism”, Basil Blackwell, 1983

[31] B. Anderson, "Imagined Communities: Reflections on the Origin and Spread of Nationalism”, Verso, 1991

[32] T. H. Eriksen, Nations in Cyberspace". A lecture delivered at the ASEN conference, London School of Economics 27 March 2006. [Online]. Available:

http://www.tamilnation.org/selfdetermination/nation/erikson. htm. Access date July 2008

[33] S. K. Moore, A. Gardner, "Megacities by the Numbers", IEEE Spectrum, 6/2007

[34] M. Hardt, A. Negri, "Empire", Cambridge, Harvard University Press, 2000

${ }^{1}$ Jean-Jacques Rousseau wrote already in the $18^{\text {th }}$ century "One of the greatest disadvantages of large states, the one which above all makes liberty most difficult to preserve in them, is that the legislative power cannot manifest itself directly, and can act only by delegation. That has its good and its evil side; but the evil outweighs the good. A legislature made up of the whole citizen body is impossible to corrupt, but easy to deceive. Representatives of the people are hard to deceive, but easy to corrupt; and it rarely happens that they are not so corrupted. ... Now, it is possible to enlighten someone who is mistaken; but how can you restrain someone who 
is for sale?"[3]

${ }^{2}$ In Switzerland, in canton Zurich, an indirect initiative - i.e. a proposal of legislative initiative that has to be considered by parliament - can be launched by an individual citizen, and yet it does not block legislative work indeed.

${ }^{3}$ The value of daily financial transactions on the international market that amounted to $\$ 2.3$ billion in 1983 has risen to $\$ 130$ billion in 2001[14].

${ }^{4}$ Phineas T. Barnum, founder of the famous Barnum Circus, stated "You can fool all of the people some of the time, some of the people all of the time, but you can't fool all of the people all of the time."

${ }^{5}$ See Web site of the Principia Cybernetica Project where the Global Brain Group works http://pespmc1.vub.ac.be/ 